\title{
LEARNING FROM HISTORIES OF GENDER AND RACIAL SEGREGATION IN AGRICULTURAL EDUCATION AND EXTENSION WORLDWIDE
}

\author{
Margreet van der Burg
}

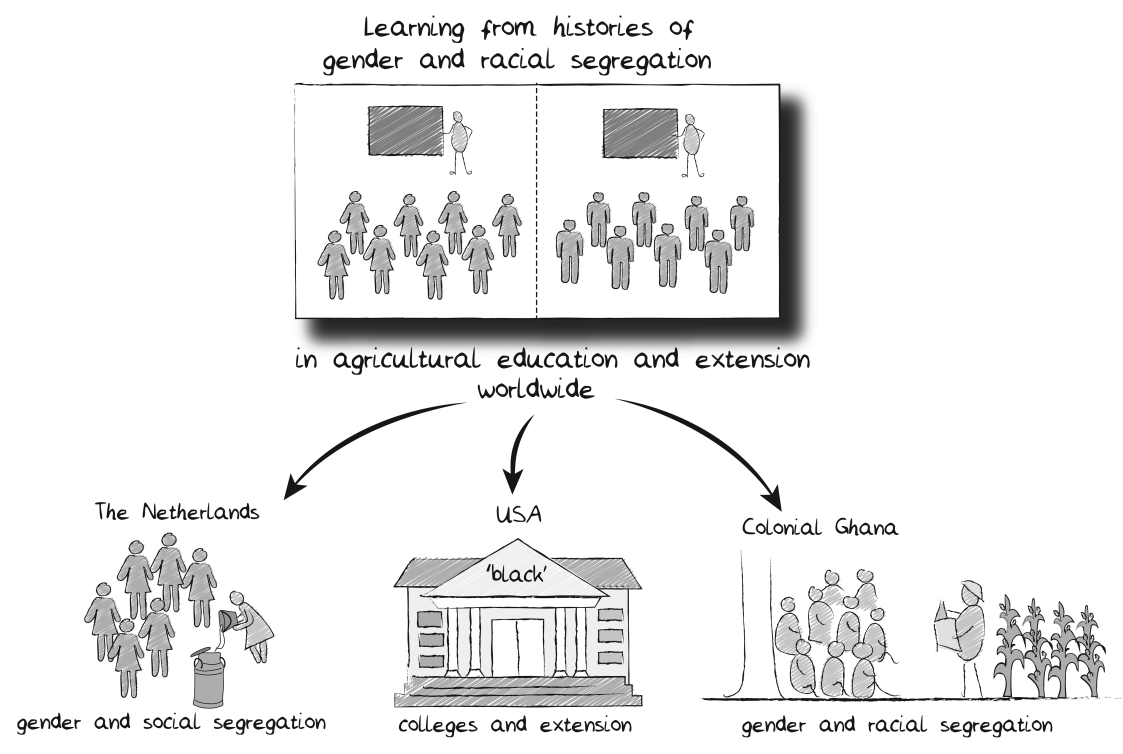

Agricultural education under debate: segregation and built-in biases

Agricultural education, including extension, ${ }^{1}$ is highly praised for contributing to the prosperity of farmers and nations through science-based agriculture. Enrolment in agricultural education and participation in extension are widely considered key to advance modernisation, development, or innovation. Agricultural education has commonly been referred to as a crucial part of the 
triptych of research, education, and extension through which states and agricultural organisations institutionalised and internationalised their cooperation to endorse agriculture-related policies.

For more than 150 years, critical insiders and outsiders have been debating the content and structure of agricultural education. Nevertheless, critiques and alternatives evoked by emancipatory movements of organised small-holders, wage labourers, women, religious minorities, and colonised and former enslaved peoples have been mostly forgotten. According to Van der Burg (2002, 2010), leaders of the first feminist wave urged to fully serve women and let them participate and profit equally as educated change agents. Instead, state-supported agricultural education started with specific programmes for women in the early 20 th century which focused on home economics adapted to farm and rural life. Few schools successfully offered professional qualification in agricultural domains to women as propagated by first-wave feminists, and then mostly without state support. The feminist-inspired professional qualification centred on specialisation in women's traditional agricultural domains, such as dairy processing, poultry raising, and horticulture. However, it was not easy for graduates-mainly women from better-off families - to gain recognition or employment as women professionals.

Agricultural education systems appeared to serve the farming populations but were, in fact, segregated systems: along with social stratification related to farm types and sizes, segregation manifested also globally according to gender and in the USA also by race. Similar segregation principles were later adopted by colonial regimes and their successors as 'adapted education' (Domosh, 2015). Segregation was justified as adaptation to the life and circumstances in respective farm and rural lives.

From the 1970s onwards, growing global solidarity and social equality claims, as well as the second feminist wave, inspired to highlighting the unfairness and ineffectiveness of segregated education. Margaret Mead (1976, p.11), for example, put the finger on structurally built-in biases and the disastrous effects of this segregated agricultural education system. In a speech she called it discrimination and emphasised the need to combine all farming skills without gender distinction:

What is needed are departments or schools in which all the skills related to food-including plant genetics, animal husbandry, veterinary skills, nutrition, child development, food management, etc.- - are taught without discrimination to both men and women.

Since then, small-scale initiatives have resulted in minor increases in the participation of women in formerly male-dominated branches of agricultural education. Nowadays, addressing food insecurity and climate change is widely considered impossible without substantially advancing social and gender equality (Quisumbing et al., 2014). Furthermore the UN Sustainable Development Goals (SDGs) 5 (gender equality) and 10 (reduce inequalities) demand a systemic change away from segregation in agricultural education systems. Accordingly, 
Afrina Choudhury and Paige Castellanos (2021) conclude after reviewing recent practices and suggestions that filling the participation gaps is not enough. They call for addressing social and gender norms in the curriculum.

This chapter argues that in-built gender and racial bias and segregation constrain systemic change in agricultural education despite common calls to ensure equal involvement in agricultural change. This chapter examines how 'adaption' or 'accommodation' (van der Burg, 2019) to diverse social groups constrains the advancement of equality in agriculture through the built-in segregation, including gender and race biases, in the foundation of agricultural education systems. Through a historical perspective, the chapter scrutinises how and why segregation has become part of the foundational roots of national agricultural education systems worldwide. It shows how agricultural education was part of politics fostering both a science-based agricultural sector and a smooth integration of farming populations into processes of modernisation, development, and innovation. These two aims were brought together, but separately addressed in agricultural education systems; accommodating and in parallel reinforcing segregation, based on gender, racial, and other social norms.

This chapter provides the example of three national historical cases-the Netherlands, USA, and colonial Ghana-to illustrate the transnational interconnectedness in views and underpinnings, in particular concerning gender and racial segregation. It then explicates the stickiness encountered in attempts to change built-in segregation and biases by discussing the provided options and the results of previous efforts for change. The chapter concludes by stressing the need for the combination and integration of formerly segregated curricula (Mead, 1976) and the need for a normative approach to achieve transformative change (Choudhury and Castellanos, 2021). This chapter concludes that integration as opposite to segregation - and not only inclusion as opposite to exclusion-is required to widen perspectives on knowledge to work for the advancement of both livelihoods and equality of farming people.

\section{History of segregation in agricultural education}

\section{Education to effect agricultural innovation and rural development}

From around the 1850s, rural and farming elites in Europe and the Americas pushed agricultural innovation and rural development in close connection with their peers in politics and the government. Around the $1900 \mathrm{~s}$, farmers firmly joined to influence policies through their organisations, syndicates, and unions. Through national and international publications, study visits, and conference exchange, together they created a growing and further professionalising international community of practice in the Christian Western world. In this transnational context they shared their visions and set out the direction, basic lay-outs, and adaptations for national and regional specifics. They invested in learning from the natural sciences and promoted innovation based on new scientific 
insights gained through experimentation and systematic data collection. They obtained state support for their initiatives to promote research and diverse types of agricultural education (e.g. van der Burg, 2002, 2010).

\section{The Netherlands: gender and social segregation}

The case of the Netherlands is exemplary for many European countries. Earlier work (Van der Burg, 2002, 2010, 2017) reveals the Dutch discussions and changes in detail, and contextualise them in a transnational context. The Dutch study by Van der Burg $(2002,2017)$ showed that among agricultural policy-makers a distinction was made between the better-off 'decent' male farmers advancing or newly taking up farming and the existing majority of less prosperous smallholding farmers. Science-based agricultural education was set up for this first group with the option to become a professional in the agricultural sector, for instance to teach others as part of the moral obligation to support less privileged farmers. The latter group was often depicted as 'others' to care for, as rough and backward, kept in the dark, and deprived of new findings and insights. They were not to be blamed for their 'ignorance' but surely considered in need for support to 'better' lives. Learning to practice science-based agriculture was the way set up to have them integrated into the modern economy and nation. This was accompanied by formative campaigns and especially educating the women as 'spiritual mothers' was considered crucial to strengthen the farming population in their patriotic, moral, and religious virtues (van der Burg, 2002, 2010, 2017).

In 1909, a new type of state-supported agricultural education was established for women which put their work and life in the centre. Along with traditionally women's farm tasks, also hygiene, first aid, healthy diets, clean and airy living conditions, and later ergonomically sound working methods, were taken into the curriculum as adopted to farm circumstances. Also, as in many European countries, the agricultural identity was kept in the name: landbouw-huishoudonderwijs (Netherlands and Flemish Belgium), écoles ménagères agricoles (France and French Belgium), and Landwirtschaftliche Haushaltungsschule, later Ländliche Haushaltschule (German speaking countries) (e.g. van der Burg, 2002, 2017; Van Molle, 2006; Caniou, 1983; Wörner-Heil, 1999).

Various education types, which differed in duration and subjects, were created to accommodate not only to gender but also social background and type of farming. In this way, agricultural education reflected in its horizontal and vertical set up the gender division of farm tasks in correspondence with family farming and rural gender norms, and social status of a regional farm type. Accommodation to these gender norms appeared in the normalisation of the segregation. Although no specific law prohibited individuals from enrolling in education marked for other groups, this was not done in practice as was best visible for gender segregation. Besides differences in course duration and subjects, the segregation additionally included institutional inequality, since there were smaller budgets for women's than men's education. 
Gradually, Dutch landbouw-huishoudonderwijs expanded within the Dutch agricultural education system, to include women-oriented schools and courses, teacher qualifications, and governmental inspection. Girls of the farming and rural elite were especially called to qualify as landbouw-huishoudteachers to educate their less fortunate 'sisters.' Meanwhile, while working within the same education system alongside male peers-including brothers and fathers-in functions such as agricultural counsellors, they could internally bridge and coordinate. Through this landbouw-huishoudonderwijs, these female teachers created a strong foundation for extension, organisation, community development, and social work for and with farm women. After World War II, the farm women's education branch gradually became the education trajectory for rural girls by removing the agricultural components, until it was discontinued in 1968. As part of the Western agricultural development process towards specialisation, farm women and their specific responsibilities and potential in farming disappeared from sight.

\section{Farm family ideology reflected in gender- specific orientation and segregation}

For the start of the women-specific landbouw-huishoudonderwijs, the national agricultural conference of 1905 in the Netherlands was decisive. Male participants based their decision on economic grounds. They argued that improvement of farm men's work could only be successful if farm women would cooperate to their full potential as well. Connections were made between a future of an economically viable agricultural sector, securing a stable and healthy rural population and 'modern' living conditions, whilst also addressing problems of growing rural outmigration. Farm women's domains were acknowledged as important to secure healthy farm families. Education in home gardening and the processing of milk, meat, and vegetables would enable women to produce quality food for their own household use and for sale. This was extended to the work done by women under male control, like milking cows, watering cattle, feeding young animals, chickens, and pigs, as well as weeding, haying, and harvesting.

By distinguishing gender-specific domains in the farm as a whole, the underlying approach was holistic and systemic. At the same time, the segregated system contributed to the formalisation and reinforcement of normative gender borders that had been quite fluid in the various farm practices before. Its formative character to support modernisation resonated and reinforced the existing gender norms as well. Farm family ideology was successfully merged with bourgeois ideals of complementarity between partners in married couples. The agricultural education system supported that the male head of the farm family was 'the' farmer; there was no place for a 'second' farmer. The hidden curricula encouraged women to act as the safekeepers of good farm family virtues. They were kept away from learning to master farm management and male farm domains. In practice, they nevertheless experienced how the interests of the farm business, the farmhouse, and the farm family often overlapped and easily conflicted. 
The alleged complementarity heavily mismatched with reality if a partner was absent, got sick, or died, or if two women intended to partner together. The segregation also discouraged to anticipate how women's work was affected by new methods taught to men. This was never substantially redressed: neither the underlying gender-specific rules and arrangements of family farming, nor any gender-specific impacts or (in)equalities.

\section{USA: 'black' colleges and extension for formerly enslaved men and women}

Agricultural education in the USA developed along structures of racial segregation in American society. The first Morill Act, from 1862, granted land to every state for establishing colleges for agricultural and industrial (mechanic) education-the so-called Land Grant colleges. As explained by Marcus Comer et al. (2006), the Southern states were authorised to establish separate colleges for African Americans, but due to slavery and a lack of specific earmarking, only three so-called black institutes were established. After the Civil War in 1865 and the abolition of slavery, five new 'black' colleges followed. After recession and fierce racial riots, most new biracial laws were again overturned in the $1880 \mathrm{~s}$, including the Civil Rights Act of 1875. The Southern states made it illegal for African Americans to vote and attend schools with white Americans. When passing a second Morrill Act in 1890 to increase land grants, Southern obstruction was prevented by adding a 'separate but equal' provision for black colleges. Seventeen states received funding for these so-called 1890 Land Grants, plus the Tuskegee Institute - the latter did not receive a land grant but had a similar curriculum. Soon the Land Grant colleges also knew home economics to serve agricultural and rural development.

The Smith-Lever Act of 1914 regulated extension work on agriculture and home economics (Ramussen, 1989), formally establishing the Cooperative Extension System under the US Department of Agriculture (USDA) and resonating the Commission of Country Life's mission to revitalise agriculture and rural life. The Land Grant colleges had to support the services and work together to reach out to the 'black' population. This faced much resistance (Harris, 2008), such as brusque racial statements against equal budgeting from Southern senators. The final arrangement was that the USDA could withhold funds if any injustice was claimed. This 'triumph in prejudice' has been long criticised as stagnating the African American extension work. Despite continuous calls for rectifying discrimination and exclusion (e.g. Wilkerson, 1938), it took until the 1960 s to enact. Although racial and gender segregation has been formally rejected and redressed in the US since the late 1960s, a 2009 report points to decreasing gender gaps, yet also to continuing underrepresentation of Black, Hispanic, and Native American students in agricultural education (National Research Council, 2009). 


\section{Underlying racial and gender norms as part of the social and cultural agenda}

The Cooperative Extension came under the care and supervision of the USDA Farm Bureau with a division for Home Economics, which became an independent Bureau of Home Economics in 1923. Farm and home demonstrations as well as clubs were organised for segregated groups of farmers according to gender, race, and generation. Mona Domosh (2015) emphasises the underlying social and cultural agenda of modernising USA agriculture, which included all aspects of farm and rural life. Domosh argues that the 'black' branches were instrumental in teaching African Americans how to assimilate to white, middle-class Americans. This resonates with how in the Dutch example middle-class views were coupled to farm family ideology.

Domosh finds specific racially defined differences between white and black racialised home demonstration since the 1920s. As in the Dutch example, USA home demonstration or clubs covered home food production, health and sanitation, and life conditions. White women were increasingly approached as modern consumers, while African American women were trained in sanitation, health, and 'improvement' of life. This coincided with the new practice in Federal policy to mark African Americans farm and home demonstration agents by race. Carmen Harris (2008) has found appointment forms that named their functions as 'Negro Home Demonstration Agent' or 'Negro Agent' and forbade the use of any other title. Following Harris among other scholars, Domosh (2015) connected this racial approach to the underlying belief that African Americans were inherently and bodily 'problematic' and in need of 'improvement' within the dominating culture of segregation and white supremacy. Therefore, beyond teaching better farming techniques, this education was set up to prevent malnutrition and diseases and ever growing outmigration among African Americans by ensuring they would have 'fit bodies' and 'morality' so crucial to increase agricultural productivity. More systematic research is needed to assess how strict the lines were kept in varying socio-economic contexts such as the Great Depression. Various examples evidenced that non-white women's extension agents ignored the divisions and encouraged women to income generation activities in South Carolina, Alabama, East Tennessee, and New Mexico (e.g. Harris, 2009; Walker, 1996; Jensen, 1986).

\section{Colonial Ghana: gender and racial segregation as mirrored in colonial areas}

The final case, colonial Ghana, exemplifies how colonial powers around the turn of the 19th century responded to the growing need to secure qualified plantation managers and stable food supply. For the latter, the model of 'adapted education' based on the USA Tuskegee Institute for African Americans was considered applicable to Africa and piloted in colonial Ghana. Various authors point to 
the model's appeal by demonstrating that Tuskegee received study visits and job invitations from all over the world. Three Tuskegee graduates were employed in colonial Togo (German Togoland) to boost agricultural productivity. In 1909, the idea of founding a 'Tuskegee-in-Africa' in Liberia was launched. Later, the British transferred the model into other colonial areas, including the Pacific and Cyprus (Comer et al., 2006; Steiner-Khamsi and Quist, 2000; Domosh, 2015). US writings, lectures, and Tuskegee visit reports were also published in Dutch with comments to consider the model for educational efforts in the Dutch colonies Surinam and Indonesia (Dutch East Indies) (e.g. Schmalhausen, 1909, esp 209-218; Bromet, 1905).

Gita Steiner-Khamsi and Hubert Quist (2000) address how Achimota College in colonial Ghana (Gold Coast) was showcased by the British colonial power to advance education programming in colonial Africa. They characterise 'adapted' education as implemented in Achimota according to the Tuskegee model, i.e., as 'adapted to the mentality, aptitudes, occupations and traditions of the various peoples' (Steiner-Khamsi and Quist, 2000, p. 274). They critically examine how the Tuskegee model was adjusted and received in colonial Ghana in the 1920s. According to Steiner-Khamsi and Quist, Achimota College prompted the Africanisation of the curriculum, adapted it to its rural environment, and emphasised appreciation and mastery of techniques, and industriousness in new labour methods. This caused tensions, being publicly contested as segregationist and racist. Mistrust was expressed about the aim to let students return to their villages as chiefs, teachers, housewives, farmers, medical assistants, or artisans, instead of moving into towns. The colonised educated elite critiqued Achimota College for settling generations for a life in the rural areas, of servitude to the colonial master and of confinement to tribal life. It was also criticised for revitalising tribal practices that resonated with the colonisers' fantasies of the idyll of savage life. The suspicion was voiced that 'adapted' education implied a 'backward' orientation instead of a 'forward' cultural adaptation to join in national pride, urbanisation, and modernisation. Similarly, the newspaper Gold Coast Leader in 1924 equalled adapted education with inferior education. And the missionaries critiqued that Christian converts would be confused to learn what was first abandoned as 'pagan' practices. Interestingly, the colonised elite challenged the potential racial bias but not the gender one, nor the embedded gender segregation. In the end, the promise of Achimota in colonial Ghana was not upheld; in the 1950s the features of rural and cultural 'adaption' were reduced to the African languages, history, and arts.

\section{Qualifying 'adaption' as rural accommodative approach}

Steiner-Khamsi and Quist recount how in 1926 the Gold Coast Leader directly attacked the US-based Phelps-Stokes Fund for having promoted the HamptonTuskegee model as a blueprint for Achimota College. The influence of a study mission journey by the Fund through West Africa and visiting Ghana was 
considered crucial. The Fund aimed to apply methods which had proved helpful for African Americans to 'the members of their race in Africa' (Jones, 1922, p. xii). It aspired to address many prevailing gaps, such as between white and black, African Americans and their distant African cousins, European and African civilisation, educational theory and practice, and Christian faith and work. Its study mission report by mission leader Jones provides insight into the underlying vision; it persistently refers to the 'adaption' concept labelled as 'African adjustment' with explicit reference to the Tuskegee Institute.

According to the report, the study commission hardly found any schools providing agricultural education or education for girls. Its recommendations were accompanied by detailed examples of schools, farm and home demonstrations, and study clubs in the African American education system. The report stressed focussing on the rural community, since Africa was overwhelmingly rural and superimposed by urban education already. The report recommended using the daily and wider African context in school materials and lessons; for instance, village market transactions and problems encountered in the dairy, barn, market, or home. Regarding home life, both boys and girls were said to be included in formative education regarding habits, attitudes, and homemaking in which the copying of Western lifestyles was critically questioned. This education was considered most important for girls, since women were considered key to changing village and economic life. In this, the report matched Western ideas for women's education.

The critical article in the 1926 Gold Coast Leader referred to a well-known adversary of 'adapted education,' W. E. B. Du Bois. The newspaper echoed Du Bois's argument that the white world wanted the black world to study agriculture, keeping Africans in country districts and depriving them of a decent income (Steiner-Khamsi and Quist, 2000). Later, Du Bois (1932) bridged the controversy. He also acknowledged the shortcomings of 'classical' black colleges and incorporated this into his earlier critique of institutes like Tuskegee. The first were ridiculed for including useless education in Latin and Greek. The latter were rejected for depriving black students of intellectual challenges and making careers. The dependency of these institutes on endowments by white philanthropists was detested since the training of an industrious black labour force was considered in their economic interest. In 1932, Du Bois claimed that the radically changing world required him to switch and call for having all black youth prepared and equipped for modern citizenship; and to change the curricula for both types of institutes by including economics, trades, and social-political awareness. He politicised segregation as a means to downplay black voices who he called upon to become independent and well-educated and informed citizens.

Mabel Carney (1936) nevertheless kept fiercely defending the Tuskegee model as not racial. She stressed that the model comprised 'rural' adaption, similar to that offered to the white rural population in the US. She emphasised the connection to what rural living offered, compared to what was normal for urban students: taking this background into account was the way towards equality. 
The man behind the Tuskegee model, African American first director Booker T. Washington seemed to have followed the same reasoning and cautiously warned against claiming social equality, instead of gradually gaining it (Bromet, 1905).

\section{Beyond segregation and bias in agricultural education}

Also after the Second World War, most states and philanthropic and other international organisations adapted agricultural education as 'technical assistance' in cooperation with Western colleges and universities. The invested tradition of gender segregated agricultural education was largely continued. FAO as a new player to ensure food security internationally also started with separate units for 'home economics' and 'agriculture.' The period can be characterised by further expansion of transnational copying as already demonstrated regarding the three historical cases. The striking parallels, for which the cases served as examples, reflect built-in bias and inequalities in the agricultural development agenda until today. These were also repeatedly challenged and therefore provided many suggestions and pilots to learn from.

\section{Addressing structurally built-in inequalities in the development agenda}

Ester Boserup (1970) is often cited as the first feminist scholar questioning farm women's limited options and the underlying history of farm women's education. Boserup pointed at the impact of having overlooked women in agriculture politically and epistemologically. Others have stressed how women's agricultural contributions became obscured as part of Western middle-class ideals and practices of domestication (Rogers, 1980) or 'housewifisation' (Mies, 1986). Cornelia Flora (1985) has underlined how colonial powers and later postcolonial national governments continued to build their national agricultural education system on the long-standing assumption that men were the primary producers.

Meanwhile, new studies exposed how gender, class, and racial segregation and bias were built in colonial and post-colonial agricultural education systems, e.g. for Belgian Congo, Kenya, Egypt, Nigeria, and German Togo (resp. Yates, 1982; Staudt, 1982; Jensen, 1994; Osuala, 1987; Zimmerman, 2010). Research further demonstrated its worldwide spread and impacts (Berger et al., 1984; Saito and Weidemann, 1990; FAO, 1993). All mentioned authors claimed to offer women extensive agricultural education instead of home economics even if it included some agricultural components since these merely focused on food for household food security.

However, this criticism did not prompt radical change. Janice Jiggins et al. (1997) reported limited success but also warned about decreasing investments in agricultural research and extension to affect particularly farm women in developing countries. Similar claims were made and not fulfilled for Western countries, as Gloria Leckie (1996, p. 311) expressed in the case of North America: 
Farm women today need sound agricultural information and knowledge [...] since 'farmer' represents the most non-traditional role that women in agriculture can have, they continually confront a system which has not been attuned to their talents, needs or viewpoints. The barriers they face prompt many questions about how women gain the information and expertise $[\ldots]$ to farm successfully in the long run.

The interest in improving agricultural education for women revived in the 2000s. It coincided with the urgency to address severe food shortages and revive smallholding agriculture, especially in Africa. In 2011, the FAO renewed its mission by combining agricultural productivity with gender equality in agriculture, and the world-wide ranging CGIAR institutes of the Consortium of International Agricultural Research launched a full-blown gender strategy, with gender as cross-cutting theme (van der Burg, 2019). Shortly after, the FAO and CGIAR gender experts compiled a diagnostic volume, Gender in Agriculture. Closing the Knowledge Gap (Quisumbing et al., 2014), which also restated the importance of agricultural education for women to achieve the formulated development aims. Still, recent research overviews provide evidence of the continuation of gender issues and gaps in agricultural and rural development programming. These again highlight ways to overcome the neglect of women in farming and of their knowledge bases (Bock and Shortall, 2017; Fletcher and Kubik, 2017; Sachs, 2019; Sachs et al., 2021).

\section{Suggestions and initiatives to overcome divides}

Although FAO responded right at the start of the UN Decade for Women in 1975 by fully integrating women in its rural and agricultural development programmes and projects (van der Burg, 2019; FAO, 1993), renewed action was needed in 2011. Still, many of the older recommendations remain valuable. For instance, Berger et al. (1984) suggested focussing on farm couples and include both partners' activities, in line with Mead's proposal. They stressed to also include women farm managers in such an integrative approach. Berger et al. also warned against falling back to a home-economics orientation, or substituting male agricultural extensionists with female ones without levelling their position and changing the programme contents. Jiggins et al. (1997) added the need for recognising diversity and not sticking to a single universal model for all. They explicated male bias as constraining reforms. They also suggested group extension to smoothen access for women as it would 'calm the fears of male extension agents, husbands, and women about transgressing norms of approved social contact' (Jiggins et al., 1997, s.p.). In the end, mainly small-scale pilots with practical solutions and efforts to interrelate research, development, and extension were initiated. No solid focus or recommendations to reform or transform the agricultural education institutions or systems as such were found. 
Choudhury and Castellanos (2021) have recently taken up the question again of how to produce agricultural change while including all in farming. Based on a robust literature review, they applaud the continuous stream of suggestions but highlight the need to take it further and include targeting social inequalities with transformative intent. They assess the Farmer Field Schools (FFS) as having most potential since they already offered, from the 1980s onwards, hands-on agricultural training for agriculture producer groups and claim to include participants' own knowledge, experiences, and needs while balancing between local knowledge and adapting scientific concepts to the local context. Choudhury and Castellanos suggest, from a gender transformative approach, to tackle community and household gender dynamics and norms by addressing societal inequities and power relations within the curriculum. Based on pilots, they explain how gender roles, norms, and practices were addressed in combination with production-focused agricultural training to also enable men to optimally engage in such discussions. Awareness and discussion sessions were built upon the trust fostered between participants and facilitators during the technical agricultural part. Especially women's effectivity could be raised by understanding the constraints or barriers to their agriculture productivity. However, Choudhury and Castellanos also warn that donors' focus on limited project time and short-term results needs to be challenged.

\section{Discussion and conclusion}

In this chapter, the historical and global biases in the foundations of agricultural education systems were made visible by pointing at their gender, social, and racial segregated roots, in various examples as being worldwide transferred, taken up, and internalised. Decision-makers created different types of education to adapt or accommodate to existing practices and underlying norms concerning family, income generation, farm labour, and care arrangements as a point of departure. Such an accommodative approach was certainly not serving claims to equally profit from new opportunities. In fact, the types mirrored hierarchies along gender, race, and other forms of social stratification - in budgets, teachers' positions, and educational contents - despite the fact that many participants also experienced their marginal and segregated inclusion as a window of opportunity to another world. Through time, these foundational premises appeared hard to change, even if highly debated by society. The underlying norms have been solidly reinforced, engrained, and internalised. Meanwhile, small-scale alternatives could not obtain enough support to scale up sustainably to enforce durable change.

The chapter concludes that lifting segregation without integration of all farmrelated persons and subjects into teaching contents and methods, will not provide transformative results. Crucial farm activities and the underlying normative basis that was formerly overlooked, need to be addressed in the integration process. A transformative approach would match with a systemic approach 
of awareness raising that agriculture, farm types, and education are interwoven as social systems including social hierarchical positions and notions. It is time to fundamentally discuss and address not only the inclusion of women but also the integration of formerly called farm men's and women's domains while addressing restraining gender and racial norms and biases based in farm family ideology. The attitudes related to former racial segregated agricultural education deserve more research to explore further detailing of how institutional racial bias in subjects, teaching contents, and methods is present and can be redressed. When taking up agricultural education as a way forward to integrate farming populations into urgent needed change, this must be taken seriously to optimally profit from new investments. The SDG goals for gender equality and reduced inequalities (5 and 10) can provide direction to transform agricultural education systems to work with the various farming groups in socially just and respectful, and in agriculturally productive and ecologically sound ways.

\section{Note}

1 This includes both formal (certified) and informal forms of education organised and subsidised by institutions such as governments, (I)NGOs or grassroots organisations, and commercial parties (Ragasa, 2014).

\section{References}

Berger, M., V. DeLancey and A. Mellencamp (1984). Bridging the gender gap in agricultural extension. Washington, DC: ICRW.

Bock, B.B. and S. Shortall (eds.) (2017). Gender and rural globalization. International perspectives on gender and rural development. Wallingford/Cambridge, MA: CABI.

Boserup, E. (1970). Women's role in economic development. New York: St. Martin's Press.

Bromet, M.S. (1905). De Neger-Kwestie. Een lezing over Booker T. Washington. Amsterdam: S.A. Van Looy.

Burg, M. van der (2019). 'Change in the making': 1970s and 1980s building stones to gender integration in CGIAR Agricultural Research. In: Sachs, C.E. (ed.). Gender, agriculture and Agrarian transformations: Changing relations in Africa, Latin America and Asia. London: Routledge, 35-57.

Caniou, J. (1983). Les fonctions sociales de l'enseignement agricole féminin. Études Rurales 92, 41-56.

Carney, M. (1936). Desirable rural adaptations in the education of negroes. Journal of Negro Education 5(3), 448-454.

Choudhury, A. and P. Castellanos (2021). In: Sachs, C.E. et al. (eds.). Routledge handbook of gender and agriculture. London: Routledge, 251-263.

Comer, M.M., T. Campbell, K. Edwards and J. Hillison (2006). Cooperative Extension and the 1890 land-grant institution: The real story. Journal of Extension 44(3), 1-6.

Domosh, M. (2015). Practising development at home: Race, gender, and the “development" of the American South. Antipode 47, 915-941.

Du Bois, W.E.B. (1932). Education and work. Journal of Negro Education 1(1), 60-74.

FAO (1993). Agricultural extension and farm women in the 1980s. Rome: FAO. 
Fletcher, A.J. and W. Kubik (eds.) (2017). Women in agriculture worldwide. Key issues and practical approaches. London: Routledge.

Flora, C. (1985). Women and agriculture. Agriculture and Human Values 2(1), 5-12.

Harris, C.V. (2008). "The Extension Service Is Not an Integration Agency": The idea of race in the cooperative extension service. Agricultural History, 82(2), 193-219.

Harris, C.V. (2009). "Well I just generally bes the president of everything": Rural Black Women's empowerment through South Carolina home demonstration activities, Black Women, Gender and Families 3(1), 91-112.

Jensen, J.M. (1986). Crossing ethnic barriers in the Southwest: Women's agricultural extension education, 1914-1940. Agricultural History 60(2), 169-181.

Jensen, K. (1994). Who carries the load? Who carries the cash? Work and status among Egyptian farm women. Frontiers: A Journal of Women Studies 15(2), 133-152.

Jiggins, J.R., K. Samanta, J.E. Olawoye, J. Aguilera, and D.E. Tempelman (1997). Improving women farmers' access to extension services. In: Swanson, B.E., R.P. Bentz and A.J. Sofranko (eds.). Improving agricultural extension. A reference manual. Rome: FAO, 73-80.

Jones, T.M. (1922). Education in Africa. A study of West, South, and Equatorial Africa by the African Education Commission, under the Auspices of the Phelps-Stokes Fund and Foreign Mission Societies of North America and Europe. New York: Phelps-Stokes Fund.

Leckie, G.L. (1996). 'They Never Trusted Me to Drive': Farm girls and the gender relations of agricultural information transfer. Gender, Place \& Culture 3(3), 309-326.

Mead, M. (1976). A comment on the role of women in agriculture. In: Tinker, I., and M.B. Bramsen (eds.). Women in development. Washington, DC: AAAS / Overseas Development Council, 9-13.

Mies, M. (1986). Patriarchy and accumulation: Women in the international division of labour. London: Zedbooks

National Research Council (2009). Transforming agricultural education for a changing world. Washington, DC: The National Academies Press.

Osuala, J.D. (1987). Extending appropriate technology to rural African women. Women's Studies International Forum 10(5), 481-487.

Quisumbing, A., R. Meinzen-Dick, T.L. Raney, A. Croppenstedt, J.A. Behrman and A. Peterman (eds.) (2014). Gender in agriculture. Closing the knowledge gap. Rome/ Dordrecht: FAO/Springer.

Ragasa, C. (2014). Chapter 17. Improving gender responsiveness of agricultural extension. In: Quisumbing et al. (eds.). Gender in agriculture. Closing the knowledge gap. Rome/Dordrecht: FAO/Springer, 411-431.

Ramussen, W.D. (1989). Taking the university to the people: Seventy-five years of cooperative extension. West Lafayette: Purdue University Press.

Rogers, B. (1980). The domestication of women. Discrimination in developing societies. London: Kogan Page.

Sachs, C.E. (ed.) (2019). Gender, agriculture and Agrarian transformations: Changing relations in Africa, Latin America and Asia. London: Routledge.

Sachs, C.E., L. Jensen, P. Castellanos and K. Sexsmith (eds.) (2021). Routledge handbook of gender and agriculture. Oxon/New York: Routlegde.

Saito, K., and C.J. Weidemann (1990). Agricultural extension for women farmers in Africa. Washington, DC: WorldBank.

Schmalhausen, H.E.B. (1909). Over Java en Javanen. Nagelaten geschriften. Van Kampen.

Staudt, K. (1982). Women farmers and inequities in agricultural services. In: Bay, E. (ed.). Women and work in Africa. Boulder, CO: Westview, 207-224. 
Steiner-Khamsi, G. and H.O. Quist (2000).The politics of educational borrowing: Reopening the case of Achimota in British Ghana. Comparative Education Review 44(3), 272-299.

Van der Burg, M. (2002). 'Geen tweede boer'. Gender, landbouwmodernisering en onderwijs aan plattelandsvrouwen in Nederland, 1863-1968. Hilversum: Verloren.

Van der Burg, M. (2010). Rural women's voices and the identification of rural women's issues within the landscape of international organisations, 1889-1940. In: Ernst, W. (ed.). Grenzregime. Geschlechterkonstellationen zwischen Kulturen und Raumen der Globalisierung. Berlin: LIT Verlag, 203-227.

Van der Burg, M. (2017). Professionalising farm women, recognizing their integrated food roles: The Netherlands, 1880-1950. In: Ambrose, L.M. and J. Jensen (eds.). Women and agriculture. Professionalizing rural life in North America and Europe, 1880-1965. Ames, IA: University of Iowa Press, 65-85.

Van Molle, L. (2006). Gendering through agricultural education in Belgium, c. 18601914: A Matruska Model, Conference paper XIV International Economic History Congress, Session 14.

Walker, M. (1996). Home extension work among African American Farm Women in East Tennessee, 1920-1939. Agricultural History 70(3), 487-502.

Wilkerson, D.A. (1938). The participation of Negroes in the federally-aided program of agricultural and home economics extension. Journal of Negro Education 7 (3), 331-344.

Wörner-Heil, O. (1999). Die Wirtschaftlichen Frauenschulen des Reifensteiner Verbandes als neuer Schultyp in der modernen Berufsbildung. Ein Beitrag zu den Anfängen des ländlich-hauswirtschaftlichen Bildungswesens. In: Heidrich, H. (Hg.). Frauenwelten. Arbeit, Leben, Politik und Perspektiven auf dem Land, Bad Windsheim, Bad Windesheim, 99-119.

Yates, B.A. (1982). Colonialism, education and work: Sex differentiation in Colonial Zaïre. In: Bay, E. (ed.). Women and Work in Africa, London: Routledge, 127-152.

Zimmerman, A. (2010). Alabama in Africa: Booker T. Washington, the German Empire, and the globalization of the new south. Princeton: Princeton University Press. 


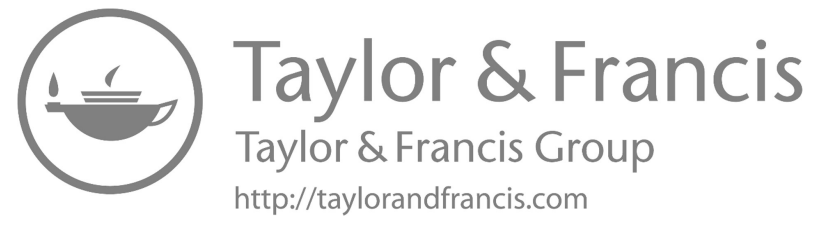

